\title{
Looking in from the Outside
}

\author{
Maris Peters
}

\section{Jeff Johnson. The New Theatre of the Baltics. From Soviet to Western Influence in Estonia, Latvia and Lithuania. Jefferson, North Carolina, and London: McFarland \& Company, 2007.}

The attempt to capture, record and to some extent analyse historical developments while they are still taking place, is a brave undertaking. This is no less true for either literary or theatrical developments in the context of sweeping historical changes. Historians justifiably claim that some temporal distance is needed after times of rapid or intensive change to put things into perspective, and to allow a stable standpoint for discussion and evaluation to emerge. In his book on the evolving theatrical scene of the three Baltic States, what he himself has termed a "snapshot" (p. 8), Jeff Johnson has bravely attempted to defy this need for temporal perspective, to some extent substituting for it his own geographical perspective as a non-native speaker and an outside observer. His goal is to trace the developments in theatre caused by the changes from the Soviet period, through the regaining of independence by the three Baltic States, and culminating in their achievement of European Union membership. His narrower focus is looking at cultural phenomena as trauma, and the inability to cope with changes, as he follows the national theatres' efforts to balance between survival as national theatres and the impending pressures toward internationalisation.

The attempt to create a voice for the theatre of the three Baltic States in itself is noble, yet, as becomes painfully obvious from Johnson's list of bibliographical material and cited written sources, little is available yet in English on the theatre of the three Baltic States. Thus, it may be argued in favour of Johnson's study, that any attempt to make this information available for a wider audience should be welcomed. Since the scene of the so-called new theatre is still evolving, most of the relevant materials written by locals would inevitably be in their own languages. There are few exceptions like Jaak Rähesoo's book on Estonian Theatre ("Estonian Theatre", 1999, 2003, 2008), which gives invaluable information on the background but does not cover very recent developments neither in length nor detail. Carried by his enthusiasm, yet admitting his almost non-existent previous knowledge of the three countries and without knowledge of the local languages, Johnson has been forced to rely on the meager materials available to him in the language he knows, and to supplement this with the local people's willingness (and most likely limited time resources) to give him necessary additional background information. Whatever conclusions he has drawn must be seen with reservations, considering the patchy and limited resource base. Needless to say, the way such filtered information influences the author is just as significant as the objective question whether the information is right or accurate. 
It is thus best to begin a more detailed scrutiny of Johnson's text with the warning implicit in Daniel Gerould's foreword (p. 1): this book is a "speculative investigation". Tiny statements like what the Lithuanians think of Estonians (p. 6) or how Finns "assure" him of what he will find (p. 23) create the feeling that though the book endeavours to put some stereotypical notions right, yet in the process others are unwittingly created. For example, the author allows Anneli Saro to voice the view - knocking westerners - that the West tends to romanticize the theatre of the Soviet era (p. 24-25). Another sign of unwitting stereotypes could be the blanket definitions of new theatre in the three Baltic States, clearly stressing that each one of them centers on a different aspect: director - actor - playwright. The theatrical scenes are certainly more versatile than that, a topic to be addressed more thoroughly by future research. A third evidence of the selectiveness of the author's factual base is that though the Soviet period and mass deportations are stressed, the author happily forgets that many people escaped to the West (see, for example, p. 13). For the time being, the reader should take all such claims with a pinch of salt.

The book abounds in other small but significant factual errors: Külli Paulus is certainly not a "he" (p. 23), Tallinn ought to be spelled with double " $n$ " (p. 24), the first mass deportation certainly did not happen in 1944 (p. 152). However, the author achieves something valuable in recording the views and opinions of the people he has met, capturing how they see and analyse themselves as pertains to the theatrical scene of the moment. This book certainly does create snapshots that will become irreplaceable research material for future investigators, and not only for the international but national ones. Johnson's book further points out how difficult it is to describe and analyse with any precision and relevance something that is still too much "alive and kicking", not to mention doing it for an audience that lacks much of the background information that those inside their own processes take as self-evident.

Johnson's book also proves how quickly such materials become outdated: the statement that "funding issues will be resolved" (p. 19) might not hold true yet. The present global economic slow-down will inevitably influence theatres everywhere, including those in the three Baltic States, thereby adding another chapter worthy of the inclusion: "crisis and attempts at survival". After all, this thought-provoking book lacks a summary or conclusion: as if hinting evocatively at its own open-endedness and adding a provocative "to be continued".

For other reviews of the book see: Anneli Saro "The New Theatre of the Baltics" in Journal of Baltic Studies 2008, No. 39, pp. 539-541 and Maris Peters "Eesti, Läti ja Leedu teater ameeriklase pilguga" in Sirp, 23.05.2008. 